\title{
Effect of Terminalia catappa Fruit Meal Fermented by Aspergillus niger as Replacement of Maize on Growth Performance, Nutrient Digestibility, and Serum Biochemical Profile of Broiler Chickens
}

\author{
David Friday Apata \\ Department of Animal Production, University of Ilorin, P.M.B. 1515, Ilorin 24001, Nigeria \\ Correspondence should be addressed to David Friday Apata, dfapataunilorin@yahoo.com
}

Received 9 June 2010; Accepted 6 August 2010

Academic Editor: Triantafyllos Roukas

Copyright (C) 2011 David Friday Apata. This is an open access article distributed under the Creative Commons Attribution License, which permits unrestricted use, distribution, and reproduction in any medium, provided the original work is properly cited.

\begin{abstract}
A feeding experiment was conducted to investigate the effect of fermented Terminalia catappa fruit meal (FTCM) with Aspergillus niger as replacement for maize on broiler growth performance, nutrient digestibility, and serum biochemical constituents. Dietary maize was replaced by FTCM at 0, 20, 40, 60, or 80\%. One hundred and eighty one-day-old Shaver broiler chicks were randomly allocated to the five dietary treatments, three replicate groups of twelve chicks each for a 42-day period. There was no significant difference $(P>.05)$ in the feed intake, weight gain, and feed; gain ratio between the broilers fed on $40 \%$ FTCM diet and the control group. The apparent digestibilities of nitrogen, crude fibre, and fat decreased significantly in broilers fed higher levels ( $>40 \%$ ) of FTCM replacement diets compared with the control or lower FTCM diets. Serum concentrations of total protein, albumin, and globulin were decreased $(P<.05)$ on $80 \%$ FTCM fed broilers. Serum cholesterol, creatinine, and glucose were not significantly $(P>.05)$ altered among treatments. The activities of aspartate and alanine aminotransferases and alkaline phosphatase were significantly $(P<.05)$ increased with higher FTCM replacement. The results indicate that FTCM could replace up to $40 \%$ of dietary maize in the diets of broiler chickens without adverse effect on growth performance or serum constituents.
\end{abstract}

\section{Introduction}

The high cost and scarcity of conventional feed ingredients constitute major problems facing commercial poultry production in the developing countries of the world. In Nigeria, maize is the most commonly used source of energy for poultry and usually constitutes $40 \%-60 \%$ of industrially formulated poultry diets. The high cost of maize and other cereals is due to the competition between man and farm animals for grains, and the seasonal production. Many unconventional tropical feed resources, especially crop seeds and their by-products which have potential for use as alternative sources of feed for poultry, could be exploited to reduce cost and limit the dependence on maize [1-3].

One of such is the fruit of the Terminalia catappa tree, which is abundant in the tropics, where it is grown for ornamental purposes. The plant forms layers of canopy and branches which bear clusters of fruits. This fruit, also known as Almond fruit, has membranous epicarp, succulent mesocarp, and fibrous endocarp that enclose the seed. The Terminalia tree has a conservative estimated yield of $75 \mathrm{~kg}$ of fruits per year, which have long been wasted in the field. These fruits, if collected, could be used in animal feeds. Although the fruit provides natural sources of soluble carbohydrates, phosphorus, and fibre [4], the presence of secondary plant metabolites, also referred to as antinutritional factors (ANFs), such as haemagglutinin, tannin and phytic acid in the raw seed could interfere with growth rate and nutrient utilization when fed to rats unless these ANFs are eliminated or reduced to insignificant levels by heat treatments [5-7]. The high proportion of fibre $\left(200 \mathrm{~g} \mathrm{~kg}^{-1}\right)$ in the whole fruit [3] also limits the 
extent to which it can be used directly in diet formulation for monogastric animals, especially poultry, which lack the appropriate digestive enzymes for degrading fibre $[8,9]$.

With other fibrous crop by-products, their nutritional value is known to be improved through solid-state fermentation (SSF) which breaks down the high-fibre materials by the action of microorganisms, particularly fungi [1012]. Moreover, it has been shown that SSF could induce degradation of antinutritional and toxic components in plant feedstuffs [13-15]. Studies by Iyayi and Aderolu [16] showed that diets containing fibrous agroindustrial by-products fermented with Trichoderma viride culture significantly enhanced laying hens' performance. Hong et al. [17] and Feng et al. [18] found that soybean meal fermented with Aspergillus oryzea was highly digestible and chicks fed the meal exhibited improved growth performance, increased concentrations of serum immunoglobulin and total phosphorus, and decreased urea nitrogen level. Adebiyi [19] concluded that fermentation with mono and mixed cultures of fungi, which contained Aspergillus niger, Trichoderma viride, and Rhizopus oligosporus, was beneficial for improved utilization of the potential of cowpea seed hull in the diets of meat-type chicken. However, this improvement could be less with high-fibre tree fruits [20].

At present, the data about the effect of fermented whole fruit from T. catappa on the performance of poultry are limited. Therefore, this experiment was conducted to evaluate the growth performance, nutrient digestibility, and serum biochemical constituents of broiler chickens fed diets containing $A$. niger fermented whole T. catappa fruit as replacement for maize.

\section{Materials and Methods}

2.1. Preparation of Fermented Terminalia catappa Fruit Meal. Mature and ripe fruits from T. catappa tree were collected within the campus of the University of Ilorin, Nigeria. Samples $(150 \mathrm{~kg})$ of the whole fruit were washed to remove dirts, sun-dried for 10 days, milled, and then subjected to SSF process. The fungus used for fermentation was Aspergillus. niger TC-4 and the stock were obtained from the Microbiology Laboratory, University of Ilorin.

In preparing suspension, A. niger TC-4 was cultivated on Potato-Dextrose Agar (PDA) at $28 \pm 1{ }^{\circ} \mathrm{C}$ for 7 days, after which it was subcultured to obtain a pure suspension containing $5 \times 10^{4}$ spore $\mathrm{ml}^{-1}$ following the procedure outlined by Hesseltine [23]. A batch $(1 \mathrm{~kg})$ of the T. catappa whole fruit meal was autoclaved at $121^{\circ} \mathrm{C}$ for $15 \mathrm{~min}$. Autoclaved meal was cooled to room temperature for $1 \mathrm{~h}$, hydrated with distilled water at a ratio of $1: 1.5(\mathrm{w} / \mathrm{v})$, and inoculated with $20 \mathrm{ml}$ of spore suspension of $A$. niger per $\mathrm{kg}$ of wet meal. The meal was thoroughly mixed and fermented in an air-tight plastic bucket for 7 days. At the end of the fermentation period, $A$. niger fermented $T$. catappa fruit meal was covered by a thin layer of black mycelium which knitted the substrate into a cake. The fresh fermented cake was then reautoclaved at $121^{\circ} \mathrm{C}$ for $15 \mathrm{~min}$ to destroy A. niger and sun-dried for 5 days. The dried product was ground in the mill, packed in polythene sack, sealed and stored at ambient temperature until sampled for analysis, and mixed into diets described below.

2.2. Chemical Analysis. All analyses were performed in triplicate. Fermented T. catappa fruit meal (FTCM) and T. catappa fruit meal (TCM) were analysed for their proximate and detergent fibre contents by the methods of AOAC [24] and Van Soest et al. [25], respectively. Tannin was quantified gravimetrically based on the method of Joslyn [26]. Phytic acid was determined by the colorimetric technique of Wheeler and Ferrel [27] as modified by Rao and Deosthale [28]. Oxalate was assayed using the procedure described by Ranjhan and Krishna [29].

2.3. Diets, Chicks, and Management. Five diets (230 g crude protein $\mathrm{kg}^{-1}$ ) were formulated by replacing maize with FTCM at $0,20,40,60$, and $80 \%$ levels (Table 1 ). The diet without FTCM served as control. One hundred and eighty one-day-old Shaver broiler chicks of equal male and female were obtained from a local hatchery. The birds were divided into five groups of 36 chicks each, which were randomly allocated to the five dietary treatments using a completely randomized design. Each treatment had three replicate cage units of 12 chicks. The chicks were allowed free access to water and experimental diets. Routine management was followed throughout the study period of $42 \mathrm{~d}$. The initial and weekly body weight of broilers was measured in each cage. Feed intake value was obtained from weekly records by subtracting the weight of feed remaining at the end of each week from the total weight introduced during the week. Feed: gain ratio was calculated by dividing the average amount of feed intake per broiler by the average weight gain for each replicate group.

2.4. Digestibility Trial. On day 35, a digestibility trial was carried out with the broiler chickens. Weighed quantities of the diets were supplied and faeces were collected over $72 \mathrm{~h}$ in plastic sheeting placed under the wire mesh floor of the cage using the total collection method. Faeces were collected every $24 \mathrm{~h}$, weighed, and stored at $4^{\circ} \mathrm{C}$. At the end of the trial, the daily samples collected from broilers in each replicate cage were pooled into 1 sample, oven dried $\left(70^{\circ} \mathrm{C}\right.$ for $\left.20 \mathrm{~h}\right)$, weighed and ground with approximately $10 \%$ retained, and stored in airtight Kilner jars. Duplicate samples of diets and dried faeces were analysed for proximate components by AOAC [24] methods and the values were used to compute apparent nutrient digestibility.

2.5. Blood Sampling and Serum Constituents Assay. At the end of the 42-d period, two chickens were randomly selected from each replicate and whole blood samples were collected from the wing vein into clean dry test tubes and allowed to stay at room temperature for $3 \mathrm{~h}$. Samples were centrifuged at $1600 \times \mathrm{g}$ for $15 \mathrm{~min}$ to harvest the serum. Serum samples were stored at $-20^{\circ} \mathrm{C}$ until thawed and used for biochemical analysis. Serum total protein, albumin, globulin, creatinine, glucose, and cholesterol were determined by the methods of Sirois [30] and alanine aminotransferase (ALT, EC 2.6.1.2), 
TABLE 1: Formulation $\left(\mathrm{g} \mathrm{kg}^{-1}\right)$ of the experimental diets.

\begin{tabular}{|c|c|c|c|c|c|}
\hline & \multicolumn{5}{|c|}{ Diets } \\
\hline & 1 & 2 & 3 & 4 & 5 \\
\hline \multicolumn{6}{|l|}{ Ingredients } \\
\hline Maize & 450.00 & 360.00 & 270.00 & 180.00 & 90.00 \\
\hline FTCM $^{\mathrm{a}}$ & 0.00 & 90.00 & 180.00 & 270.00 & 360.00 \\
\hline Soybean meal & 324.00 & 324.00 & 324.00 & 324.00 & 324.00 \\
\hline Wheat offal & 115.00 & 113.00 & 110.00 & 108.00 & 103.00 \\
\hline Cassava flour & 34.00 & 36.00 & 39.00 & 41.00 & 46.00 \\
\hline Fish meal & 30.00 & 30.00 & 30.00 & 30.00 & 30.00 \\
\hline Blood meal & 10.00 & 10.00 & 10.00 & 10.00 & 10.00 \\
\hline Bone meal & 20.00 & 20.00 & 20.00 & 20.00 & 20.00 \\
\hline Oyster shell & 10.00 & 10.00 & 10.00 & 10.00 & 10.00 \\
\hline DL-Methionine & 1.00 & 1.00 & 1.00 & 1.00 & 1.00 \\
\hline Lysine & 1.00 & 1.00 & 1.00 & 1.00 & 1.00 \\
\hline Vit/min premix ${ }^{b}$ & 2.50 & 2.50 & 2.50 & 2.50 & 2.50 \\
\hline Salt & 2.50 & 2.50 & 2.50 & 2.50 & 2.50 \\
\hline Total & 1000.00 & 1000.00 & 1000.00 & 1000.00 & 1000.00 \\
\hline \multicolumn{6}{|l|}{ Proximate composition ${ }^{\mathrm{c}}\left(\mathrm{g} \mathrm{kg}^{-1}\right)$} \\
\hline Dry matter & 970.0 & 967.8 & 960.1 & 963.6 & 958.6 \\
\hline Crude protein & 230.1 & 227.4 & 226.8 & 223.5 & 221.5 \\
\hline Crude fibre & 45.2 & 52.6 & 58.1 & 73.5 & 84.9 \\
\hline Fat & 41.5 & 49.1 & 56.3 & 65.2 & 73.8 \\
\hline Ash & 37.5 & 36.3 & 35.6 & 35.3 & 34.9 \\
\hline Metabolisable energy $\left(\mathrm{MJkg}^{-1}\right)$ & 12.02 & 11.67 & 11.39 & 11.26 & 11.18 \\
\hline
\end{tabular}

aFermented Terminalia catappa whole fruit meal.

${ }^{b}$ Provided $1.5 \mathrm{mg}$ retinol, $25 \mathrm{mg}$ cholecalciferol, $16 \mathrm{mg} \alpha$-tocopherol, $1 \mathrm{mg}$ menadione, $0.8 \mathrm{mg}$ thiamine, $2.4 \mathrm{mg}$ riboflavin, $14 \mathrm{mg}$ nicotinic acid, $4 \mathrm{mg}$ calcium D-pantothenate, $1.4 \mathrm{mg}$ pyridoxine, $10 \mathrm{mg}$ cyanocobalamin, $0.4 \mathrm{mg}$ folic acid, $0.02 \mathrm{mg}$ biotin, $120 \mathrm{mg}$ choline chloride, $0.62 \mathrm{mg}$ zinc bacitracin, $36 \mathrm{mg}$ avaten, $40 \mathrm{mg} \mathrm{Mn}, 18 \mathrm{mg} \mathrm{Zn}, 0.8 \mathrm{mg} \mathrm{Cu}, 0.09 \mathrm{mg}$ Co, $20 \mathrm{mg} \mathrm{Fe}$, and $0.04 \mathrm{mg} \mathrm{Se} \mathrm{kg}{ }^{-1}$ diet.

${ }^{c}$ Determined values except for metabolisable energy (ME), which was calculated from the published [21] compositions of the ingredients used and the ME of FTCM, was estimated from its analytical data [22].

aspartate aminotransferase (AST, EC 2.6.1.1), and alkaline phosphatase (AP, EC 3.1.3.1) activities were measured by using commercial clinical investigation kits (Wako, Osaka, Japan).

2.6. Statistical Analysis. The data from the feeding trial were subjected to one-way analysis of variance, and multiple comparisons among means were made by Duncan's multiple range test using the SPSS version 10.0 computer program [31]. Other data were compared using Student's $t$-test. All statements of differences were based on significance at $P<$ .05 .

\section{Results and Discussion}

The analytical data for T. catappa fruit meal (TCM) and fermented T. catappa fruit meal (FTCM) are shown in Table 2. After 7 days fermentation, the crude protein increased $(P<$ $.05)$ while the crude fibre and fat contents decreased significantly, particularly the fibre level by about $50 \%$ relative to the unfermented fruit meal. Fermentation induced significant $(P<.05)$ degradation of detergent fibre and antinutritional components of TCM. The reduction in neutral detergent
TABle 2: Proximate and detergent fibre composition and antinutritional components of Terminalia catappa fruit meal (TCM) and fermented Terminalia catappa fruit meal (FTCM).

\begin{tabular}{|c|c|c|}
\hline & TCM & FTCM \\
\hline \multicolumn{3}{|c|}{ Proximate composition $\left(\mathrm{g} \mathrm{kg}^{-1}\right)$} \\
\hline Dry matter & $972.0^{\mathrm{b}}$ & $965.0^{\mathrm{a}}$ \\
\hline Crude protein & $47.2^{\mathrm{a}}$ & $74.3^{\mathrm{b}}$ \\
\hline Crude fibre & $255.0^{\mathrm{b}}$ & $130.0^{\mathrm{a}}$ \\
\hline Fat & $55.5^{\mathrm{b}}$ & $39.2^{\mathrm{a}}$ \\
\hline Ash & $60.0^{\mathrm{b}}$ & $55.0^{\mathrm{a}}$ \\
\hline Nitrogen free extractives & $55.4^{\mathrm{a}}$ & $66.7^{\mathrm{b}}$ \\
\hline \multicolumn{3}{|l|}{ Detergent fibre $\left(\mathrm{g} \mathrm{kg}^{-1}\right)$} \\
\hline Neutral detergent fibre & $432.7^{\mathrm{b}}$ & $328.0^{\mathrm{a}}$ \\
\hline Acid detergent fibre & $307.6^{\mathrm{b}}$ & $242.1^{\mathrm{a}}$ \\
\hline \multicolumn{3}{|l|}{ Antinutrients } \\
\hline Tannin $\left(\mathrm{mg} 100 \mathrm{~g}^{-1}\right)$ & $62.8^{\mathrm{b}}$ & $25.7^{\mathrm{a}}$ \\
\hline Phytic acid (mg $\left.100 \mathrm{~g}^{-1}\right)$ & $17.4^{\mathrm{b}}$ & $11.2^{\mathrm{a}}$ \\
\hline Oxalate $\left(\mathrm{mgg}^{-1}\right)$ & 2.3 & 1.9 \\
\hline
\end{tabular}

a,b Means in the same row with different letters are significantly different at $P<.05$. 
TABLE 3: Effect of fermented Terminalia catappa fruit meal (FTCM) replacement for maize on growth performance of broilers at 42 days of age.

\begin{tabular}{|c|c|c|c|c|c|c|}
\hline \multirow{2}{*}{ Parameters } & \multicolumn{6}{|c|}{ Levels of FTCM replacement for maize (FRM) } \\
\hline & Control & $20 \%$ FRM & $40 \%$ FRM & $60 \%$ FRM & $80 \%$ FRM & SEM \\
\hline Feed intake (g per chicken day ${ }^{-1}$ ) & $56.80^{\mathrm{a}}$ & $55.90^{\mathrm{a}}$ & $56.80^{\mathrm{b}}$ & $52.60^{\mathrm{a}}$ & $49.80^{c}$ & 2.40 \\
\hline Weight gain (g per chicken day ${ }^{-1}$ ) & $21.0^{\mathrm{a}}$ & $19.60^{\mathrm{a}}$ & $19.40^{\mathrm{a}}$ & $15.60^{\mathrm{b}}$ & $14.70^{\mathrm{b}}$ & 1.60 \\
\hline Feed: gain ratio $\left(\mathrm{gg}^{-1}\right)$ & $2.70^{\mathrm{b}}$ & $2.85^{\mathrm{b}}$ & $2.93^{\mathrm{b}}$ & $3.57^{\mathrm{a}}$ & $3.39^{\mathrm{a}}$ & 0.80 \\
\hline
\end{tabular}

a,b,c Treatment means in the same row with different letters are significantly different at $P<.05$. SEMs, standard error of means.

TABLE 4: Effect of fermented Terminalia catappa fruit meal (FTCM) replacement for maize on apparent nutrient digestibility of broilers.

\begin{tabular}{|c|c|c|c|c|c|c|}
\hline \multirow{2}{*}{ Digestibility (\%) } & \multicolumn{6}{|c|}{ Levels of FTCM replacement for maize (FRM) } \\
\hline & Control & $20 \%$ FRM & $40 \%$ FRM & $60 \%$ FRM & $80 \%$ FRM & SEM \\
\hline Nitrogen & $69.40^{\mathrm{a}}$ & $72.10^{\mathrm{b}}$ & $70.50^{\mathrm{a}}$ & $67.70^{c}$ & $62.80^{\mathrm{d}}$ & 2.00 \\
\hline Fibre & $42.30^{\mathrm{a}}$ & $41.60^{\mathrm{a}}$ & $39.90^{\mathrm{a}}$ & $32.50^{\mathrm{b}}$ & $25.70^{c}$ & 1.10 \\
\hline Fat & $74.70^{\mathrm{a}}$ & $75.40^{\mathrm{a}}$ & $72.80^{\mathrm{ab}}$ & $65.90^{\mathrm{b}}$ & $58.60^{c}$ & 3.20 \\
\hline
\end{tabular}

a,b,c,d Treatment means in the same row with different letters are significantly different at $P<.05$. SEMs, standard error of means.

fibre and acid detergent fibre ranged between $21 \%$ and $24 \%$. Tannin and phytic acid had reductions of $59 \%$ and $35 \%$, respectively. There was a slight decrease in oxalate content.

The present study shows that fermentation changed the characteristics of T. catappa fruit meal. The increase in crude protein content of the FTCM may be due in part to the synthesis of single cell protein by the proliferation of the fungus used. This is supported by Fonseca et al. [32], who reported that microorganisms contributed microbial protein to their fermented products. The decreases in crude fibre, detergent fibre, and fat contents may be attributed to the degradation by extra cellular enzymes secreted by $A$. niger; this strain secretes a number of enzymes including alphagalactosidase, hemicellulase, and pectinase [33]. During fermentation, the enzymes secreted are known to metabolise carbohydrate as a carbon source for growth of the strain [34]. The marked reductions in phytic acid and tannin contents after fermentation might have been caused by the activity of intrinsic phytase or hydrolysis by A. niger. These findings are in agreement with Reddy and Pierson [14] and Khattab and Arntfield [35], who reported appreciable reductions in the tannin and phytic acid contents of cereals and legumes, respectively. They found that the fermentation microflora hydrolysed phytic acid into inositol and orthophosphate.

The growth performance characteristics of broilers fed diets with FTCM replacing maize are presented in Table 3. Feed intake, weight gain, and feed; gain ratio for the broilers on the $20 \%$ and $40 \%$ FTCM replacement for maize diets $($ FRM $)$ were similar $(P>.05)$ to those of the control group, while at higher FRM levels these performance characteristics were lower $(P<.05)$ than the control. There was no mortality at all levels during the feeding trial. The higher feed intake with lower levels of FRM may have occurred as a result of the flavour compounds produced during SSF which improved the palatability of the fermented meal $[36,37]$. The absence of significant difference in weight gain and feed; gain ratio of broilers fed the control diet and those fed 40\% FRM diet suggests that this level of FRM which corresponds to $180 \mathrm{~g} \mathrm{~kg}^{-1}$ FTCM in the diet can support growth and feed conversion comparable to a maize-based diet. Previous report of Bakrie [10] showed that there was an improvement in weight gain and feed efficiency of broilers fed diet containing cassava fibre fermented with $A$. niger.

The apparent nutrient digestibility values are given in Table 4. Digestion of nitrogen, fibre, and fat with $20 \%$ and $40 \%$ FRM was significantly better than those on higher levels of FRM. Digestion of nitrogen was higher with 20\% FRM. The enhanced nutrient digestibility with lower levels of FRM might have contributed to the growth pattern of the broilers, as evidenced by the increase growth rate in broilers on lower FRM diets. The reduction in nutrient digestibility with higher FRM diets may partly be a consequence of the high crude fibre in these diets (Table 1). This would affect the digestion and intestinal absorption of associated nutrients in the diets. Adeniji and Omonijo [38] reported that fibres are arranged in such a way that proteins are trapped within them offering resistance to digestion by enzymes in gastrointestinal tract of simple-stomached animals. In the present study, the residual tannin in FTCM (Table 2) could also contribute to the decrease in nitrogen digestibility observed in broilers fed higher levels of FRM. Tannin found in sorghum grains [39] and a number of legume seeds [40] have been implicated in the reduced nutrient digestibility of these feedstuffs.

The serum biochemical constituents of the broilers are presented in Table 5. Values for total protein, albumin, and globulin were similar $(P>.05)$ to the control until $60 \%$ of the maize was replaced by FTCM. Cholesterol, creatinine, and glucose concentrations were not significantly altered by dietary treatments. AST, ALT, and AP activities with the $60 \%$ and $80 \%$ FRM diets were significantly higher than the control, but the lower levels were not. The values of the serum metabolites in broilers fed 20\%-60\% FRM diets were within normal ranges [41], reflecting a normal metabolism in the broilers fed these levels of FRM diets. This observation 
TABLE 5: Effect of fermented Terminalia catappa fruit meal (FTCM) replacement for maize on serum biochemical profile of broilers.

\begin{tabular}{|c|c|c|c|c|c|c|}
\hline \multirow{2}{*}{ Constituents } & \multicolumn{6}{|c|}{ Levels of FTCM replacement for maize (FRM) } \\
\hline & Control & $20 \%$ FRM & $40 \%$ FRM & $60 \%$ FRM & $80 \%$ FRM & SEM \\
\hline Total protein $\left(\mathrm{gl}^{-1}\right)$ & $41.00^{\mathrm{b}}$ & $42.70^{\mathrm{b}}$ & $42.00^{\mathrm{b}}$ & $38.70^{\mathrm{ab}}$ & $35.70^{\mathrm{a}}$ & 1.20 \\
\hline Albumin $\left(\mathrm{gl}^{-1}\right)$ & $16.50^{\mathrm{b}}$ & $17.00^{\mathrm{b}}$ & $16.20^{\mathrm{b}}$ & $14.10^{\mathrm{a}}$ & $13.80^{\mathrm{a}}$ & 0.40 \\
\hline Globulin $\left(\mathrm{gl}^{-1}\right)$ & $24.50^{\mathrm{b}}$ & $25.70^{\mathrm{b}}$ & $25.80^{\mathrm{b}}$ & $24.60^{\mathrm{b}}$ & $21.90^{\mathrm{a}}$ & 1.30 \\
\hline Creatinine $\left(\mathrm{mgdl}^{-1}\right)$ & 0.33 & 0.35 & 0.36 & 0.41 & 0.50 & 0.07 \\
\hline Glucose $\left(\mathrm{mmol} \mathrm{l}^{-1}\right)$ & 4.10 & 4.70 & 4.80 & 3.90 & 3.70 & 0.10 \\
\hline Cholesterol $\left(\mathrm{mmol} \mathrm{l}^{-1}\right)$ & 1.50 & 1.40 & 1.40 & 1.30 & 1.10 & 0.30 \\
\hline $\operatorname{AST}\left(\mathrm{IUI}^{-1}\right)$ & $69.70^{\mathrm{a}}$ & $70.50^{\mathrm{a}}$ & $72.40^{\mathrm{a}}$ & $78.60^{\mathrm{a}}$ & $94.00^{\mathrm{b}}$ & 4.68 \\
\hline $\operatorname{ALT}\left(\mathrm{IUI}^{-1}\right)$ & $9.50^{\mathrm{a}}$ & $9.90^{\mathrm{a}}$ & $9.60^{\mathrm{a}}$ & $12.70^{\mathrm{ab}}$ & $14.30^{\mathrm{b}}$ & 1.03 \\
\hline $\mathrm{AP}\left(\mathrm{IUI}^{-1}\right)$ & $106.20^{\mathrm{a}}$ & $110.00^{\mathrm{a}}$ & $113.00^{\mathrm{b}}$ & $114.50^{\mathrm{b}}$ & $129.00^{c}$ & 5.10 \\
\hline
\end{tabular}

a,b,c,d Treatment means in the same row with different letters are significantly different at $P<.05$. SEMs, standard error of means; AST, aspartate aminotransferase activity; ALT, alanine aminotransferase activity; AP, alkaline phosphatase activity.

could also suggest that FTCM can spare dietary maize at those substitution levels. However, the decrease in total protein concentration with $80 \%$ FRM diet is an indication of reduction in protein synthesis which could probably be related to the low feed intake observed in the diet. The increases in serum AST and ALT activities with 80\% FRM diet indicate a release of the transaminases from cytoplasm into the blood stream which is probably due to the damage of the hepatocytes and/or other tissues. A similar observation has been reported by Muhammad and Oloyede [42] for chicks fed fermented T. cattapa seed meal-based diet.

In conclusion, the present study showed that the solidstate fermentation of T. catappa fruit meal using A. niger could improve the nutritional characteristics of T. catappa and decrease the inherent tannin and phytic acid components. The FTCM has a high potential as feedstuff for poultry and could be included at $180 \mathrm{~g} \mathrm{~kg}^{-1}$ to replace $40 \%$ dietary maize level in the broiler chicken feed without adverse effect on growth performance, apparent nutrient digestibility, or serum biochemical constituents.

\section{Acknowledgments}

The author is grateful to Dr. R.M.O Kayode of Food Science Department, University of Ilorin, Nigeria, for technical assistance in preparing the FTCM, to Atteh M. and Babatayo $\mathrm{K}$. for care and management of the broilers during the experiment.

\section{References}

[1] D. F. Apata, "Egg production and haematological profile of laying hens fed dietary raw or processed Prosopis africana seeds," Journal of Agricultural Research and Development, vol. 3, pp. 99-104, 2004.

[2] E. A. Iyayi and F. K. Fayoyin, "Expanding rural production through the use of low cost cassava fruit coat as alternative fibre source for broilers," in Proceedings of the Deutscher Tropentag Conference on International Agricultural Research for Development, pp. 1-8, Berlin, Germany, 2004.

[3] A. A. Annongu, N. J. Ogundu, J. K. Joseph, and V. Awopetu, "Changes in chemical composition and bioassay assessment in nutritional potentials of almond fruit waste as an alternative feedstuff for livestock," Biokemistri, vol. 18, pp. 25-30, 2006.

[4] F. A. Jeremiah, "Chemical evaluation and nutritional quality of almond fruits. (Terminalia cattapa)," in Nutritional Quality of Plant Foods, A. U. Osagie and E. U. Eka, Eds., pp. 93-94, Post Harvest Research Unit University of Benin, Nigeria, 1992.

[5] A. M. Balogun, Biochemical and nutritional evaluation of underexploited crop seeds with emphasis on the antinutritional components, Ph.D. thesis, University of Ibadan, Nigeria, 1982.

[6] D. F. Apata and A. D. Ologhobo, "Trypsin inhibitor and other anti-nutritional factors in tropical legume seeds," Tropical Science, vol. 37, no. 1, pp. 52-59, 1997.

[7] N. O. Muhammad, O. B. Oloyede, B. V. Owoyele, and J. E. Olajide, "Deleterious effects of defatted Terminalia catappa seed meal-based diet on haematological and urinary parameters of albino rats," NISEB Journal, vol. 4, pp. 51-57, 2004.

[8] A. A. Onilude and B. A. Oso, "Effect of fungal enzyme mixture supplementation of various fibre-containing diets fed to broiler chicks 1: performance and carcass characteristics," World Journal of Microbiology and Biotechnology, vol. 15, no. 3, pp. 309-314, 1999.

[9] T. O. O. Babalola, D. F. Apata, and J. O. Atteh, "Effect of $\beta$ xylanase supplementation of boiled castor seed meal-based diets on the performance, nutrient absorbability and some blood constituents of pullet chicks," Tropical Science, vol. 46, no. 4, pp. 216-223, 2006.

[10] B. Bakrie, "Improvement of nutritive quality of crop byproducts using bioprocess technique and their uses for animals," in Proceedings of the 18th National Biology Seminar, pp. 310-320, Lampung University, Bandar lampung, Indonesia, 2000.

[11] F. B. Iluyemi, M. M. Hanafi, O. Radziah, and M. S. Kamarudin, "Fungal solid state culture of palm kernel cake," Bioresource Technology, vol. 97, no. 3, pp. 477-482, 2006.

[12] E. B. N. Graminha, A. Z. L. Gonçalves, R. D. P. B. Pirota, M. A. A. Balsalobre, R. da Silva, and E. Gomes, "Enzyme production by solid-state fermentation: application to animal nutrition," Animal Feed Science and Technology, vol. 144, no. 1-2, pp. 122, 2008.

[13] H. M. Bau, C. Villaume, C. F. Lin et al., "Effect of a solid-state fermentation using Rhizopus oligosporus Sp.T-3 on elimination of antinutritional substances and modification of biochemical constituents of defatted rapeseed meal," Journal of the Science of Food and Agriculture, vol. 65, no. 3, pp. 315-322, 1994. 
[14] N. R. Reddy and M. D. Pierson, "Reduction in anti-nutritional and toxic components in plant foods by fermentation," Food Research International, vol. 27, no. 3, pp. 281-290, 1994.

[15] S. H. A. Elyas, A. H. El Tinay, N. E. Yousif, and E. A. E. Elsheikh, "Effect of natural fermentation on nutritive value and in vitro protein digestibility of pearl millet," Food Chemistry, vol. 78, no. 1, pp. 75-79, 2002.

[16] E. A. Iyayi and Z. A. Aderolu, "Enhancement of the feeding value of some agro-industrial by-products for laying hens after their solid state fermentation with Trichoderma viride," African Journal of Biotechnology, vol. 3, no. 3, pp. 182-185, 2004.

[17] K.-J. Hong, C.-H. Lee, and W. K. Sung, “Aspergillus oryzae 3.042GB-107 fermentation improves nutritional quality of food soybeans and feed soybean meals," Journal of Medicinal Food, vol. 7, no. 4, pp. 430-435, 2004.

[18] J. Feng, X. Liu, Z. R. Xu, Y. Y. Liu, and Y. P. Lu, "Effects of Aspergillus oryzae 3.042 fermented soybean meal on growth performance and plasma biochemical parameters in broilers," Animal Feed Science and Technology, vol. 134, pp. 235-242, 2007.

[19] F. Adebiyi, Fungal degradation of cowpea seed hull for utilization by meat-type chicken, Ph.D. thesis, University of Ibadan, Nigeria, 2008.

[20] V. Mlambo, F. L. Mould, J. L. N. Sikosana, T. Smith, E. Owen, and I. Mueller-Harvey, "Chemical composition and in vitro fermentation of tannin-rich tree fruits," Animal Feed Science and Technology, vol. 140, no. 3-4, pp. 402-417, 2008.

[21] NRC, Nutrient Requirements of Poultry, National Academy Press, Washington, DC, USA, 9th edition, 1995.

[22] O. Pauzenga, "Feeding parent stock," Zootechnical International, pp. 22-23, 1985.

[23] C. W. Hesseltine, "Microbiology of oriental fermented foods," Annual Review of Microbiology, vol. 37, pp. 575-601, 1983.

[24] AOAC, Official Methods of Analysis, Association of Official Analytical Chemists, Washington, DC, USA, 17th edition, 2000.

[25] P. J. van Soest, J. B. Robertson, and B. A. Lewis, "Methods for dietary fiber, neutral detergent fiber, and nonstarch polysaccharides in relation to animal nutrition," Journal of Dairy Science, vol. 74, no. 10, pp. 3583-3597, 1991.

[26] M. A. Joslyn, Methods in Food Analysis, Academic Press, London, UK, 2nd edition, 1970.

[27] E. L. Wheeler and R. E. Ferrel, "A method for phytic acid determination in wheat fractions," Cereal Chemistry, vol. 48, pp. 312-316, 1971.

[28] P. U. Rao and Y. G. Deosthale, "Tannin content of pulses: varietal differences and effects of germination and cooking," Journal of the Science of Food and Agriculture, vol. 33, pp. 10131016, 1982.

[29] S. K. Ranjhan and G. Krishna, Laboratory Manual for Nutrition Research, Vikas Publishing House, New Delhi, India, 1980.

[30] M. Sirois, Veterinary Clinical Laboratory Procedures, Donelley, St. Louis, MO, USA, 1995.

[31] SPSS, SPSS Base 7.5 for Window. SPSS, 444N, Michigan Avenue, Chicago, Ill, USA, 1997.

[32] G. G. Fonseca, E. A. Gandra, L. F. Sclowitz, A. P. A. Corrêa, and J. A. V. Costa, "Protein enrichment and digestibility of soft rush (Juncus effusus) and rice residues using edible mushrooms Pleurotus ostreatus and Pleurotus sajor-caju," World Journal of Microbiology and Biotechnology, vol. 25, no. 3, pp. 449-456, 2009.
[33] R. P. de Vries and J. Visser, "Aspergillus enzymes involved in degradation of plant cell wall polysaccharides," Microbiology and Molecular Biology Reviews, vol. 65, no. 4, pp. 497-522, 2001.

[34] P. Nigam and D. Singh, "Solid-state (substrate) fermentation systems and their applications in biotechnology," Journal of Basic Microbiology, vol. 34, no. 6, pp. 405-423, 1994.

[35] R. Y. Khattab and S. D. Arntfield, "Nutritional quality of legume seeds as affected by some physical treatments 2 . Antinutritional factors," Food Science and Technology, vol. 42, no. 6, pp. 1113-1118, 2009.

[36] G. Feron, P. Bonnarme, and A. Durand, "Prospects for the microbial production of food flavours," Trends in Food Science and Technology, vol. 7, no. 9, pp. 285-293, 1996.

[37] A. B. P. Medeiros, A. Pandey, P. Christen, P. S. G. Fontoura, R. J. S. de Freitas, and C. R. Soccol, "Aroma compounds produced by Kluyveromyces marxianus in solid state fermentation on a packed bed column bioreactor," World Journal of Microbiology and Biotechnology, vol. 17, no. 8, pp. 767-771, 2001.

[38] A. A. Adeniji and O. A. Omonijo, "The replacement value of palmkernel cake for groundnut cake in the diets of weaner rabbits," Livestock Production Science, vol. 85, no. 2-3, pp. 287291, 2004.

[39] A. J. U. Jansman, "Tannins in feedstuffs for simple-stomached animals," Nutrition Research Reviews, vol. 6, pp. 209-236, 1993.

[40] D. Jezierny, R. Mosenthin, and E. Bauer, "The use of grain legumes as a protein source in pig nutrition: a review," Animal Feed Science and Technology, vol. 157, no. 3-4, pp. 111-128, 2010.

[41] P. D. Sturkie, Avian Physiology, Cornell University Press, New York, NY, USA, 4th edition, 1986.

[42] N. O. Muhammad and O. B. Oloyede, "Effects of Aspergillus niger-fermented Terminalia cattapa seed meal-based diet on selected enzymes of some tissues of broiler chicks," Food and Chemical Toxicology, vol. 48, pp. 1250-1254, 2010. 

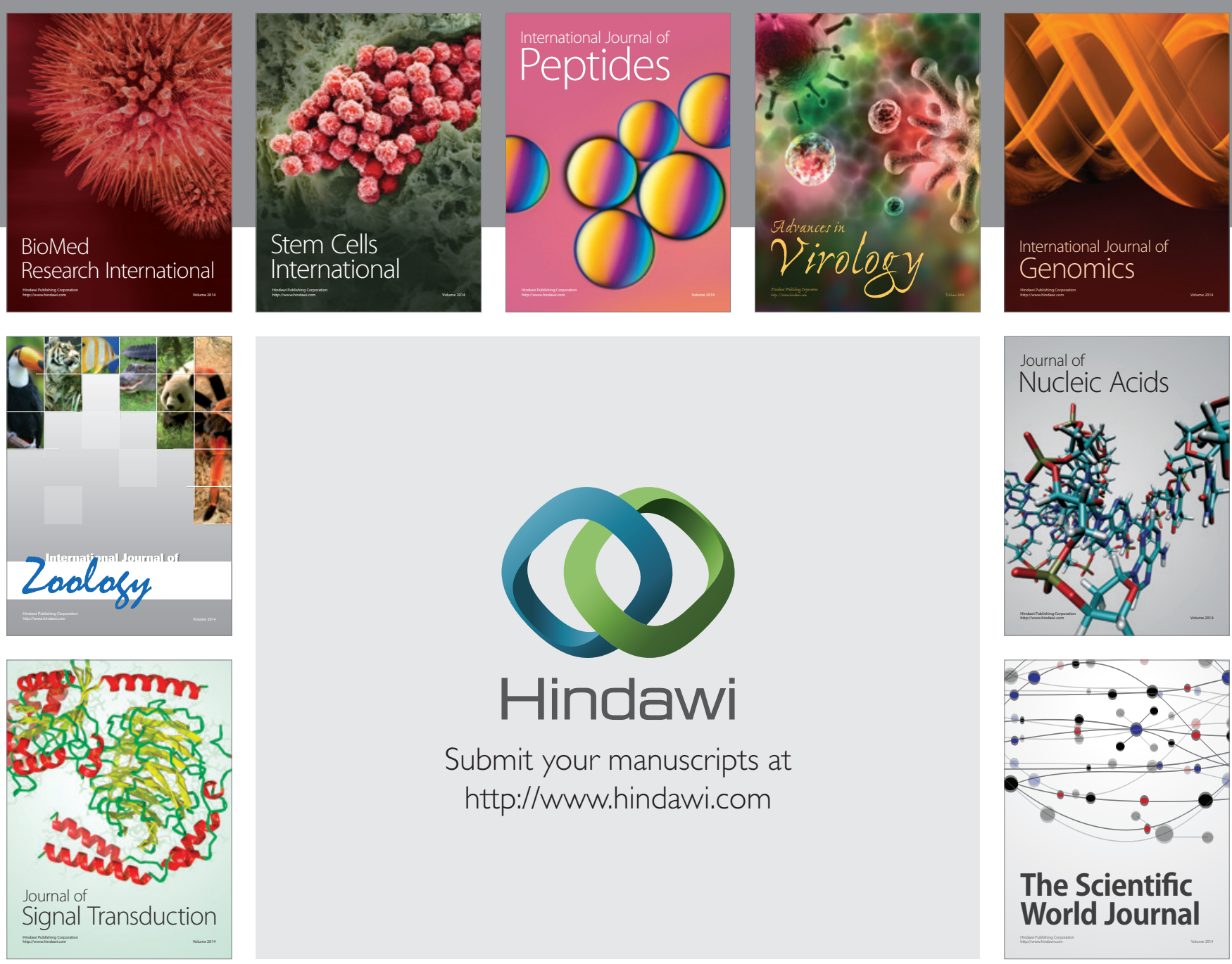

Submit your manuscripts at

http://www.hindawi.com
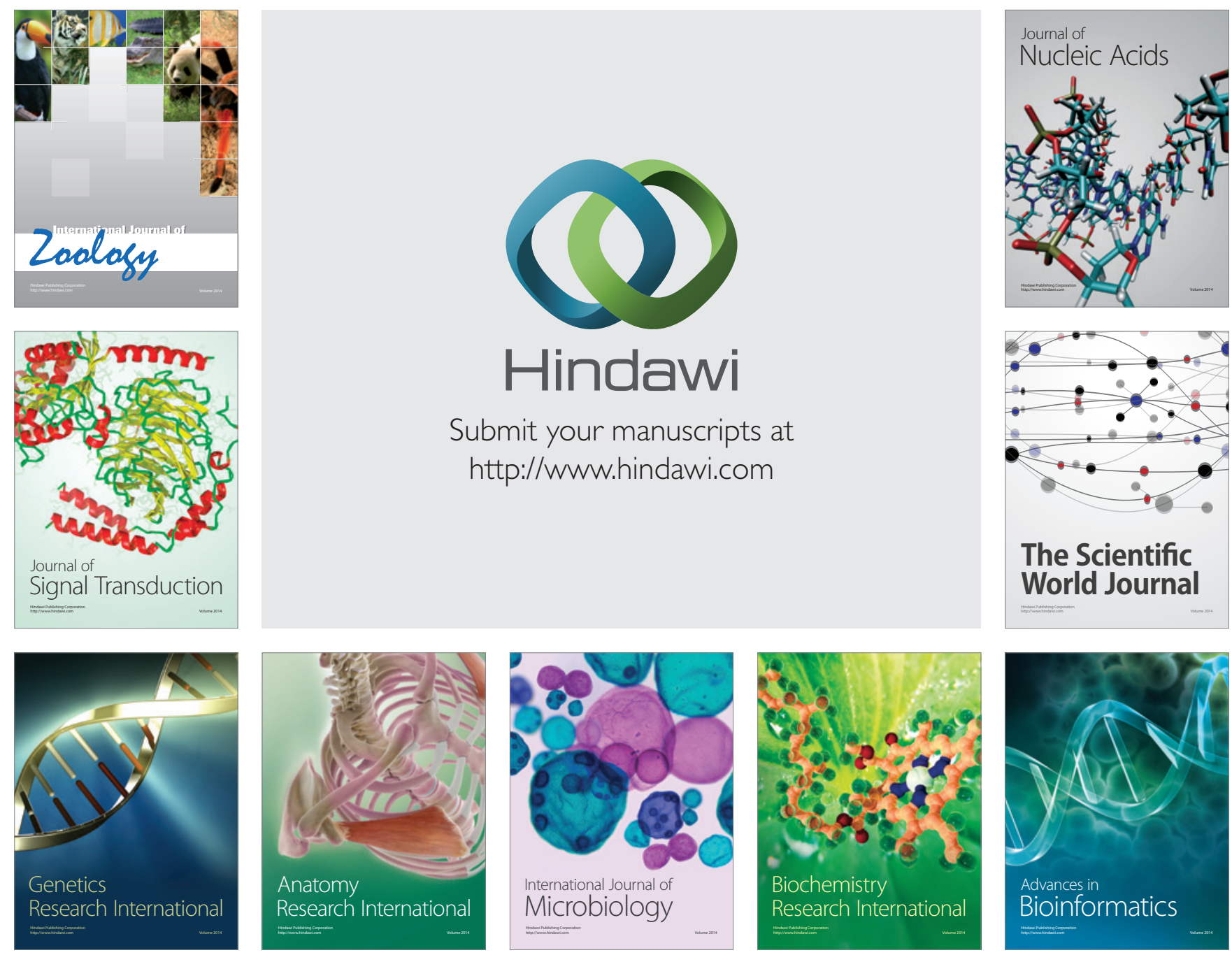

The Scientific World Journal
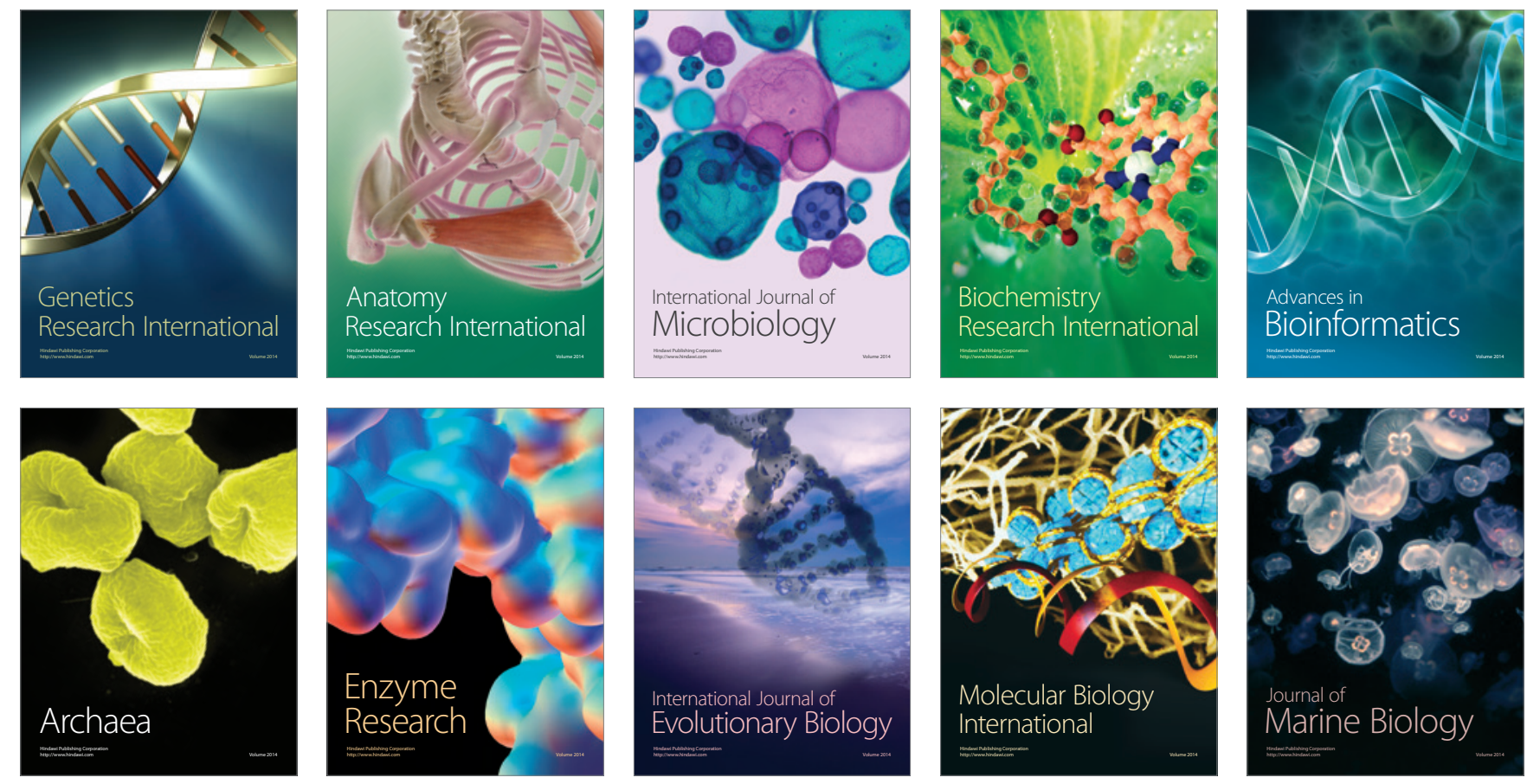